\title{
THE SETTLEMENT POLICY OF THE OTTOMAN EMPIRE AND THE IMPLEMENTATION OF THE TANZIMAT PRINCIPLES ON THE SEMI-NOMADIC PEOPLE
}

\section{SOSYAL BILIMLER DERGISI}

ANKARA UNIVERSITY JOURNAL OF SOCIAL SCIENCES

10.33537/sobild.2020.11.1.1

\section{Makale Bilgisi}

Gönderildiği tarih: Kabul edildiği tarih: Yayinlanma tarihi:

29-11-2019 30.12.2019 31.01.2020

Article Info

Date submitted: Date accepted:

Date published:

29-11-2019

30.12.2019

31.01 .2020

\begin{abstract}
OSMANLI DEVLETI'NİN İSKÂN POLITTIKASI VE TANZIMATT İLKELERININN KONAR-GÖÇER AHÂLI ÜZERINDE TATBIKKI
\end{abstract}

\section{Ahmet Samil GÜRER}

Doç.Dr., Ankara Üniversitesi, Türk Inkılap Tarihi Enstitüsü, asgurer@ankara.edu.tr

\section{Keywords}

Settlement, sedentarization, tanzimat, semi-nomadic, tribes, ottoman empire

\section{Anahtar sözcükler}

İskân, yerleşik hayat, tanzimat, konar-göçer, aşiretler, osmanlı imparatorluğu

\section{Abstract}

The sedentarization of the semi-nomadic population, in other words, the issue of their resettlement, has remained on the agenda of the Ottoman Empire from its foundation until its collapse. The first planned settlement policies were implemented to support the conquests in the Balkans especially during the establishment and development periods. After the defeat of Vienna in 1683, the Empire tried to resettle some of the nomadic tribes in some parts of Anatolia and North of Syria to provide security, increase tax revenues and open vacant lands for agriculture. The settlement practices continued in the 19th century were carried out in a more comprehensive and planned manner during the Tanzimat period. The settlement works of this period should be considered as a part of the general reform program whose principles determined by the Tanzimat Edict, such as tax, public order, military service and establishment of the central authority. In other words, the settlements which were carried out in Central Anatolia and in South East Mediterranean part of Anatolia during this period should be considered as the application of the general reform program on the nomadic population. $\ddot{o} z$

Konar-göçer ahalinin yerleşik hayata geçirilmesi, diğer bir deyişle iskânı meselesi Osmanlı Devleti'nin kurulușundan yıkılışına kadar sürekli gündeminde kalmış olan bir meseledir. İlk planlı iskân politikalar kuruluş ve gelişme dönemlerinde özellikle Balkanlar'da gerçekleştirilen fetihleri desteklemek amactyla uygulanmıștır. 1683 Viyana yenilgisini müteakiben Devlet, güvenliği sağlamak, vergi gelirlerini artırmak ve boş arazileri tarıma açmak için Anadolu'daki bazı konar-göçer aşiretleri Anadolu ve Suriye'nin kuzeyinde yerleşik hayata geçirmeye çalışmıştır. 19. yüzyılda da devam eden iskân çalışmalar Tanzimat döneminde daha kapsamlı ve planl bir şekilde gerçekleştirilmiştir. $\mathrm{Bu}$ dönemdeki iskân çalışmalarinı prensipleri Gülhâne Hatt-ı Hümayûnu ile belirlenen genel reform programinin, vergi, asayiş ve askerlik ve merkezi otoritenin tesisi gibi hususlarınin bir parçası olarak görmek gerekir. Diğer bir deyişle, bu dönemde Orta Anadolu ve Güney Doğu Akdeniz'de gerçekleştirilen iskânlar genel reform programının konar-göçer ahali üzerindeki tatbiki olarak değerlendirilmelidir. 


\section{INTRODUCTION}

Consistent and planned settlement policies are vital in the social, economic, administrative and military development of states. The Ottoman Empire which had considerable nomadic population was aware of this fact and pursued different settlement policies depending on the changing conditions from the beginning. The settlement policy implemented by the Ottoman Empire throughout its history is divided into two periods by considering the geographical locations of the settlement practices.

During the periods of establishment and expansion of the Empire, in order to improve agricultural production, increase the population and most importantly to ensure the turkification of the region in the seized territories in Rumelia, the transfer and placement of some of the nomadic Turkmen tribes in Anatolia to this region is described as "outward-looking settlement policy". Starting from the end of the 17th century, the cessation of conquests and the great loss of land have led to the general social and economic problems brought about by the reverse migration movements. For these reasons, the settlements of the nomadic people in the northern parts of Anatolia and Syria, which have been initiated starting from the end of the 17th century, for the purpose of improving agriculture, creating new taxpayers and ensuring public order, is described as "Inwardlooking settlement policy" (Orhonlu, 1978, p. 98; Halaçoğlu, 1991, p. 3-4).

It can be said that the first Ottoman settlement practices started in Anatolia with the establishment of zâviyes (convents in the rural areas), vakufs (pious foundations), derbends (military watchtowers) and villages during the foundation period (Barkan, 1942, p. 285). These settlement practices were shifted to Rumelia with the conquests started in that region. As mentioned above, these settlements were established for the purpose of turcification of the newly conquered lands, to defend them, and to ensure the continuation of the agriculture in the lands abandoned by their former holders. Although the method of forced exile of the nomadic Türkmen tribes, which caused unrest in Anatolia, was used in these settlement works, encouraging methods such as giving fertile lands to those who would go to the region voluntarily, granting fiefs such as yurtluk and timar were also applied (Aktepe, 1953, p. 300-304; Inalcik, 1954, p. 122-129).

The settlements in Rumelia continued to exist from Suleyman Pasha's first stepping on to Rumelia until the end of the 14th century and resulted in significant turkification of the region. Considering the fact that the region still has a considerable Turkish population, despite the counter-migration events of the 19th and 20th centuries and the attempts of assimilation by some Balkan states, it can easily be said that the Ottomans were successful in the outward-looking settlement policy.

The first extensive settlement works in the territories of the Empire other than Rumelia was carried out between 1691 and 1696 in the regions of Sivas, Adana, Bozok and Afyon in Anatolia, and Raqqa, Aleppo, Hama and Homs in Syria (Orhonlu, 1978, p. 55-87). The immediate reasons that forced the establishment of these settlements were the political, economic and social crises that emerged during the long-term War of the Holy League that began immediately after the Vienna defeat of 1683. These battles, which continued on four fronts for sixteen years and resulted in the loss of large amounts of land, completely emptied the central treasury. It is enough to show the collection of the extraordinary tax which it created under the name of imdâd- $\iota$ seferiyye (help for military campaign) even from the ulema, who are considered a tax-exempt segment, to show the extent of the hardship that the Ottoman finance has suffered (Halaçoğlu, 1991, p. 28-29)

When the forced collection of the said tax from Anatolian reâya (tax paying segment of the Ottoman society) combined with the terror environment created by soldiers fleeing the war, the reâya who were already in a poor economic situation have abandoned all their means of farming and immigrated to the big towns and cities, especially to Istanbul and its environs. This situation leading to the decline of agricultural production resulted in the deaths of thousands of people in Anatolia from starvation in 1687 and an even greater crisis in the Ottoman finance, a large part of which was based on agricultural taxes. Moreover, the loss of important sources of income, such as Hungary and Erdel (Transylvania), and the destruction of the lands where the battles took place were a problem in itself (Uzunçarş111, 1983, p.486-488; Shaw, 1997, p. 255.)

Therefore, the state had to implement an internal settlement policy in order to sedentarize the seminomadic tribes in Anatolia and Syria. The aim was reopening the abandoned lands of these regions to agriculture and creating new taxpayers (Orhonlu, 1978, p. 98). However, tribes such as Rissvan who were made to settle in Syria left their places and came back to Anatolia after a short period of time because of the climate and living conditions in Raqqa region not being taken into account ${ }^{1}$. This shows that inward-looking settlement policy was not completely successful.

Settlement practices in the Ottoman Empire also continued in the 18th century. In this period, the large migration movements from the lands that were lost with the Treaty of Karlowitz (1699) and Treaty of Küçük Kaynarca (1774), to the inner parts should be added to the above mentioned reasons for settlement. It is estimated that around 500,000 Crimean immigrants took refuge in the territory of the Empire in Rumelia and Anatolia especially during the migrations that started in 1785 when Crimea came under Russian rule and continued until 1800 (Halaçoğlu, 1991, p. 41-42; Uzunçarş111, 1983, p. 490-491; Shaw, 1978, p. 255).

These immigrations in the 18th century and the economic crisis and the public order problem caused by internal turmoil forced the opening of ruined and empty lands to agriculture in order to provide new sources of income to the central treasury. Since 1701, migrants have been made to settle in Kütahya-Aydın, KonyaKaraman, İçel-Teke, Ankara-Nevşehir, Sivas-Erzurum,

\footnotetext{
${ }^{1}$ About failure of the Ottoman settlement policy in Raqqa see (Çelikdemir, 2001, p.38-40; Köksal, 2006, p. 476-744; Winter, 2017, p. 256-269)
} 
Çukurova-Diyarbekir-Malatya, Raqqa-Aleppo, HamaHoms regions and Crimean Tatars have been made to settle in Rumelia region. In addition to the establishment of new settlements and the placement of new people in the lands around derbends (watchtowers) and vakifs (pious foundations), new practices such as settling nomads in their yaylaks (grazings) and kuşlaks (winter quarters) were also initiated during these settlement practices (Halaçoğlu, 1991, p. 28-43,125-143). However, the settlement policies adopted by the Ottoman government in the 17 th and 18th centuries were not so successful in producing a permanently settled society (Kasaba, 2009, p.86). Becase, Ottoman Empire's settlement policies towards the tribes were short term and temporary before Tanzimat (Köksal, 2006, p. 475).

The settlement activities, which continued in the 19th century, began to be carried out in a more systematic manner with the Tanzimat. During this period, instead of mass settlements, a method aimed at the rehabilitation of the regions was pursued, and extensive settlement practices were carried out in the central Anatolia region between 1839 and 1853, and in the southeastern Mediterranean region of Anatolia between 1865 and 1866. The settlement policy of the Tanzimat period was largely determined by the new principles introduced by the Tanzimat and the social, economic, military and administrative problems of the period. And we will try to address the issue within this framework.

\section{THE PRINCIPLES OF TANZIMAT AND REASONS FOR THE TRIBAL SETTLEMENTS}

The basic principles determined by The Tanzimat Edict were influential in the settlement policy of the Empire during the Tanzimat era, as were most of the reforms carried out during this period. Therefore, before giving details about the subject, we want to summarize some of the features of Tanzimat Edict and these basic principles it contains.

On 3 November 1839, a new era began in the history of the Ottoman Empire with the The Edict, which was read in front of the Ottoman dignitaries, representatives of non-Muslim communities, foreign diplomats and a large group of people. With this event, the idea of a century-old reform that began with Lale Devri (Tulip Era) began to bear fruit, and the Ottoman Empire took the first step towards becoming a modern state of law.

Numerous studies have been conducted and various views have been put forward on the inspiration of the ideas expressed in the Tanzimat Edict, and on the style, nature and legal value of the Edict ${ }^{2}$. These views are summarized as follows: Along with the western influences, the sources of inspiration for the ideas contained in the Edict and the sources of inspiration for the reforms carried out during the Tanzimat period were the experiences of previous reforms and the ideas of all Ottoman intellectuals and bureaucrats who supported modernization. In particular, the reforms of Mahmud II and a booklet written by Sâdık Rifat Pasha, one of the creators of Tanzimat, during his term in embassy in Vienna between 1837 and 1839 are the closest sources of inspiration (Kuran, 1994, p.136; Seyitdanlıoglu 1996). In terms of style, The Edict is reminiscent of the classical Ottoman edicts (Abdurrahman Şeref Efendi, 1985, p. 50), and In terms of legal quality, a contract-type document between the ruler and his subjects and bureaucrats (Berkes, 1973, p. 187-188). However, the essential articles on basic human rights, which constitute the crucial points of the Edict, show that it is the first harbinger of the transition to a constitutional regime.

Undoubtedly, the most important aspect of the Tanzimat Edict is its content rather than its external appearance. As pointed out above, the safety of life and property being under the guarantee of the state, the determination of a fair tax rate, and the main articles concerning basic human rights such as recruitment and determination of the duration of military service constitute the essence of this document.

As mentioned above, the settlement policy of the Tanzimat bureucrats for semi-nomadic tribes is closely related to these articles mentioned in the Edict. Therefore, it is necessary to consider the issue as part of the social, economic and military reforms carried out during the Tanzimat period and the application of Tanzimat to the nomadic people of The Empire, which will be better understood in the section "reasons for the settlement of the tribes" explained below in our study.

There was a direct relationship between the settlement of the tribes and the new tax system that the Tanzimat administrators aimed to achieve. Therefore, first of all, we want to focus on the reasons that require tax reform and the new tax system that is intended to be introduced.

The internal and external events faced by The Empire before and during the Tanzimat period had left the Ottoman treasury in a very difficult position. The loss of Serbia and Greece as a result of nationalist movements in the Balkans, the de facto loss of an eyalet (province), which is an important source of income such as Egypt, if not officially, with the revolt of Kavalalı Mehmet Ali Pasha, the endless Ottoman-Russian wars and the cost of the reforms carried out during Mahmut II left the Tanzimat statesmen with a huge financial problem. Moreover, large amounts of financial source were needed for the reforms that were intended to be carried out. In the first years of the Tanzimat period, in order to provide temporary solutions to financial problems, it was decided to take austerity measures and to issue kaime (paper money) (Mustafa Nuri Paşa, 1987, 304-305). However, the Tanzimat reformers, who believed that a long-term solution to the problem could be achieved through an orderly and fair tax system, were also working on the draft of the new tax reform.

Despite the regulations made during the reign of Mahmud II, the tax system at the time of the proclamation of the Tanzimat was still a tax order from the classical period, based on traditional fiscal practices

\footnotetext{
2 For these studies and views, see (Abdurrahman Şeref Efendi,1985, p. 49-52; İnalc1k, 1940, p. 237-263; İnalc1k, 1964, p. 602-622; Berkes, 1964 , p. 144-147; Davison, 1963, p. 36-42; Abadan, 1940, p. 31-58; Kaynar,1985, p. 164-190; Kuran,1994, p. 135-140).
} 
(Shaw, 1975, p. 421). The most disadvantageous part of this system was the collection of taxes through mültezims (tax farming holders). This, in the words of the Tanzimat Edict, meant "...handing over the political and financial affairs of the country into the hands of one person, perhaps in the agonising claws..."(Takvim-i Vekayi).

The reform that Tanzimat reformers intended to carry out in this tax system was more about the way taxes are collected. Tanzimat reformers, as stipulated in the Edict, were aiming for a tax system that would eliminate the mültezims and make the taxpayer pay directly to the state. In this system, taxes would be collected by the salaried officers of the state instead of the mültezims, and thus all of the tax revenues would flow directly to the state treasury, and the injustices caused by the iltizam (tax farming) system would be prevented. According to this plan, which was determined by a will issued on 23 February 1839, all shariah taxes, except for öşür (tithe), resm-i ağnam (sheep tax) and cizye (head tax) would be abolished, and öşür would be collected at a rate of onetenth throughout the Empire. In 1840, with an arrangement made at the rate of resm-i ağnam, which mostly concerned nomads, all taxes on animals were abolished and replaced by a tax of five cents per animal in general (Shaw, 1975, p.422).

As stated in an archive document, the implementation of this new tax scheme on nomads was only possible if they lived in a specific place permanently (Kaynar, 1985, 260). Because they did not stay in a certain place permanently, difficulties were encountered during the collection of taxes from them. Therefore, the state left the collection of taxes to the mercy of the tribal chiefs (Saydam, 1993, p. 240-241).

In addition, since tahrirs (imperial tax registers) could not be carried out on a regular basis every year, taxes were demanded based on recent tahrir, which sometimes led to nomads not being able to pay their taxes in cases such as population growth, animal diseases, and herds being destroyed (Orhonlu, 1978, p. 25). This was contrary to the principle of fair taxation, which was expressed as "an appropriate tax shall be determined according to the property and power of each individual and no more tax shall be levied on anyone" in the Tanzimat Edict (Takvim-Vekâyi). For this reason, in 1840, a decision was taken, which stated that taxes would be levied according to the power of each individual after the census of property, land and real estate (Abdurrahman Vefik, 1330, s. 58-59; Saydam, 1993, p. 241).

The first implementation of this new fiscal system planned by the Tanzimat administrators on the basis of tribes was initiated by the transformation of the Kildonlu, Tabanl, Boynu inceli and Yeni-il tribes in Ankara, Sivas, Konya, Karesi, Sanjaks into an independent muhassillık within the framework of the new administrative system (Orhonlu, 1978, p. 114).

Another reason that forced the settlement of the tribes was the idea of preventing the damage they caused to the settled population and agricultural production. Since the arrival of Turks in Anatolia, there has been a constant conflict between nomadic Turkmens in Anatolia and the settled communities, stemming from the different lifestyles adopted by them. The lifestyle required by their economic activities has made the nomadic Turkmens different from the settled people in many areas, from social and administrative organization to their religious beliefs. Turkmens, who have a feudal social and administrative organization, have adopted a heterodox Islamic understanding which is generally more tolerant in religious terms, unlike the settled people. And this often negatively affected the way they looked at each other (Ocak, 1996, p. 45).

However, the dispute between the nomads and the resident population was mainly due to the damage caused by their herds to the farmers' cultivated land while the nomads shuttled between their yaylaks and kışlaks. These groups, who did not feel the authority of the state on them, or the outlaws they housed, were also involved in illegal acts such as stealing the animals of the villagers, killing the ones who resist, raping them, and robbery on roads when they were on the move (Saydam, 1999, p. 183) ${ }^{3}$.

According to informations provided by Saydam (1993, p. 235-236) from the archival sources, governor of Bozok and Kayseri reported that the bandits of tribes stole thousands of animals of Gedincik people in 1846. Likewise, according to an another document belonging to 1848 the value of the goods and animals robbed only from the people of Ankara and Çankırı had reached 30004000 sacs in recent years. In the document dated January 12,1848 , it was stated that the people could not leave their villages because of the banditry of the tribe mentioned. And in another letter sent by the British consul in Kayseri to his embassy in Istanbul in 1848, it was stated that the villages were evacuated due to attacks by the Avşar and Kurdish tribes in Kayseri and that the Tanzimat did not show much influence in this region.

The situation was not different in Gavurdağ1 and Kozan as well. Cevdet Pasha lamented that there was no security even one or two hours outside of Adana. Because these were the area of movement of the Kozanoğulları, the largest tribe in the region. The Celikanlu and Tecirli tribes, who were wandering around Gâvurdağı and Maras, were constantly harassing the Nogay Tatars, who had been settled in the Misis after the Crimean War, and selling the goods they had robbed from the villagers in Maras. And the Ulassli tribe had taken the Payas-Aleppo road under their control and robbed passengers (Ahmed Cevdet Paşa,1980, p. 123,125,130; Kasaba, 2009, p.9798).

From time to time, some government representatives in the countryside cooperated with the tribes and plundered the villagers' threshing. For example, according to the investigation report written by Fehim Efendi, who was sent as an inspector upon the reflection of such an incident that occurred in Yozgat in 1840, Cebbarzâde Ahmed Bey, Dergâh-1 Âli Kapucubaşısı (head of the imperial door keepers) in Yozgat, Kad1 Yusuf Efendi and Müfti Emin Efendi collaborated with the Kurdish and

${ }^{3}$ Farouqhi (1976) and Demir (2017) stated that this atmosphere of terrorism caused by nomads led to the abandonment of villages by the peasants in the previous centuries. 
Turkmen tribes and had the villagers' threshing looted (Kaynar, 1985, p. 264-265).

Although the security forces were sometimes successful in stopping tribal bandits, they were far from providing a radical solution to the problem. Because when nomadic tribes committed crimes, it was not easy to find them; they moved from one sanjak to another, causing confusion about the realm of authority of the local administrators, and their crimes often went unpunished. Both the central government and the local administrators understood that a definite and permanent measure would be possible only through the settlement of all tribes (Saydam, 1993, p. 237-239).

This situation, which can be called as "a struggle between shepherd and plow" (Orhonlu, 1978, p. 40), was contrary to the basic principles of Tanzimat on the basis of human rights. Therefore, it is necessary to evaluate the settlement policy of the Tanzimat period in terms of the fundamental rights such as safety of life, chastity, honor and property, which the Sultan promised to provide to the people of all Ottoman countries in accordance with the sharia rule with the Tanzimat Edict. Because, in the words of Abdurrahman Şeref Efendi (1985, p.42), a society where these fundamental rights were not guaranteed by the state could not be considered as civilized.

The issue of recruitment, which was one of the three basic articles of the Tanzimat Edict, and which endeavored to ensure an orderly and fair system during the Tanzimat period, was another reason that made the settlement of the tribes compulsory. This is especially true for the operations carried out by Firka-i Íslahiyye (Reformation Army) in Kozan and Gavurdağı regions in 1865-1866.

The abolition of the janissaries had created a large deficit in the number of soldiers, and the military system in the established Âsakir- $i$ Mansure-i Muhammediye (Victorious Soldiers of Mohammad) army could not be bound by a fundamental rule. Primitive and very unfair methods were used to provide troops to this new army, which was named Nizâmiye after its development. According to the new recruitment procedure set by Mahmud II, the youngsters who were forcibly recruited by the recruiting officers in the provinces were transported to Istanbul under very bad conditions and sent to the regiments or ships where they would serve for the rest of their lives. Since the same proportion of troops could not be recruited from each region with this system, it had negative effects on agriculture and trade as well as on population growth. In order to eliminate this situation, which was also stated in the Tanzimat Edict, and to develop a fair and orderly recruitment system, a law adopting the kur'a (conscription) system was enacted on September 6, 1843. Kur'a system limited the period of military service, and the number of troops to be recruited was determined in proportion to the population of the region. In addition, with a draft law prepared in 1847, it was thought that the Christian subjects would be recruited, but this bill was postponed when the Christians preferred to pay poll tax to the military

${ }^{4}$ For a discussion on the relationship between sedentarization of the tribes and restoration of the central authority in the Tanzimat period see Köksal, 2006, p. 469-491. obligation (Mustafa Nuri Paşa, 1987, p. 297-302; Abdurrahman Şeref Efendi, 1985, p. 45-46; Karal, 1988, p. 178-180).

Despite these legal regulations in the military service system, the expected increase in the number of soldiers did not occur. Moreover, after the Crimean War, the soldiers' conscription became narrower and it was not possible to recruit soldiers from nomads. For this reason, there were even insurgencies in the mountainous regions of Anatolia and Lebanon. It was understood that the Kozanoğulları tribe in particular did not have a very favorable view on this issue (Ahmed Cevdet Paşa, 1980, p. 113).

Thereupon, the issue of recruiting troops from the non-Muslim subjects was raised again in 1864, and the matter was discussed in a commission chaired by Fuad Pasha, including Cevdet Pasha. During the negotiations, Cevdet Pasha drew attention to the drawbacks of recruitment of soldiers from non-Muslims in terms of religious, political and economic aspects. And he suggested that this should be given up for now, and that the tribes living in semi-detached state in Kozan, Gâvurdağı, Akçadağ and Dersim regions should be improved and recruited as soldiers, instead. Upon Sadrâzam Âli Pasha's approval of this proposal, Cevdet Pasha, who had shown great success in the formation of Bosnian regiments during his term as the inspector of Bosnia, and field marshall Derviş Pasha, were assigned the establishment and administration of Firka-i Islahiye commission for the sedentarization of the tribes in the mentioned regions (Cevdet Paşa, 1986, p. 107; Ahmed Cevdet Paşa, 1980, p. 113-116; Ahmed Lütfi Efendi, 1989 , p. 136). The rehabilitation of the tribes in Gâvurdağ1 and Kozan region and the recruitment of soldiers from the tribes living in those regions would be possible only after their settlement in these regions.

Another reason for the tribal settlements was to restore the central authority in the region, especially by ending the ayanlik (local dynasties), which had completely turned into a overlordship in Kozan 4 . One of the reasons for the military operations of the Furka- $i$ Islahiye in Kozan in 1865 and the settlements it carried out was to end the Kozanogulları dynasty, which was the most powerful ayan of Cukurova, and to establish the authority of the central government in the region ${ }^{5}$. Because the Kozanoğulları had become almost completely independent and put great pressure on the people.

The Sanjak of Kozan was divided into two parts as Kozan-1 garbi (West Kozan) and Kozan-1 şarki (East Kozan). And in the official documents of the government, although the Aghas of these two regions were given official titles, in fact, they both did not recognize the orders of the state and established independent feudal rule in their regions. Even in Adana Meclis-i Kebiri (Grand Council of Adana), it was not possible to speak openly against Kozanogulları. The defeat of the forces sent by Kavalali's son Ibrahim Pasha in order to invade the Kozan mountains by Cadirc1 Mehmed, the Agha of Kozan-1 Garbi, further increased his prestige in the region, and he completely opposed to the government's orders. In fact,

${ }^{5}$ For detailed information about this âyân family whose origin goes back to Seljuk period see Ahmed Refik, 1930, p. 162-164; Köse, 2016; Kozanoğlu, 1983; Dumont, 1979-1980, p. 374-378. 
the Kozanoğulları defeated a party sent by Kıbrislı Mehmet Pasha, and the state did not launch any more operations to Kozan after this incident (Ahmed Cevdet Paşa, 1980, p. 120-122).

The administration of Kozanoğulları was a tyrannical administration and the districts around it were in a state of semi-rebellion. Karaisals district and Menemencioğulları's Sunbas sub-district were also under the rule of Gökvelioğulları. In Gâvurdağı, there were many small principalities. Of these, Küçükalioğulları, which reigned in the Sanjak of Payas, had the pilgrimage route under their control and received tribute from the pilgrims passing by. In 1859, the tribes of Sirkint1 and Kırıntılı in Çukurova applied to the state after they were persecuted when they were under the rule of Kozanoğulları and asked to be settled (Ahmed Cevdet Paşa, 1980, p. 120-122; Halaçoğlu, 1973, s.12-13). Ending this feudal rule and liberating some of the small tribes from the oppression of the big tribes was only possible by settlement of all tribes in the region.

\section{SETTLEMENT ACTIVITIES}

Both the provincial administrators in the regions where the tribes lived intensively and the central government believed that all these problems could be solved only through a planned and comprehensive settlement. That's why in 1839 it was decided that all the tribes and clans would be brought under the order in accordance with the Tanzimat principles. Sultan Abdulmecid also dealt with this issue personally and gave orders to save the tribes from their nomadic state and to give them a comfortable and safe life in which they could engage in trade, craft and agriculture (Saydam, 1993, p.245, 255).

However, Tanzimat dignitaries, were aware that the settlement attempts to be started without a preliminary study would be unsuccessful. That's why they asked the provincial administrators to prepare detailed reports on the determination of the places where the tribes lived, their number, the appropriate places where they could be resettled and their chieftains in 1840, and also sent inspectors to important areas (Saydam, 1993, p. 245426). However, yaylaks and kışlaks were limited as an urgent measure to protect the settled people from the damage caused by the tribes (Orhonlu, 1978, p.114; Halaçoğlu, 1991, p. 7).

The first large-scale settlement was carried out in Central Anatolia, where a nomadic population of approximately 35,000-40,000 people was settled between 1839-1853. The settlement in Bozok, Konya and Ankara between 1841-1843 were partially successful. However, between 1848 and 1850, significant achievements were provided in the settlement practices in Ankara, Sivas, Amasya, Çankırı and Kayseri. The effective methods applied by Mehmed Vecihi Pasha, the governor of Ankara, who conducted the settlement works, played a major role in these achievement. The Pasha applied the dispersed settlement method such as placing tribes in small groups in remote areas. By this method, Vecihi Pasha intended to prevent the members of the tribes from coming

${ }^{6}$ Information about the resettlement of tribes in Central Anatolia is summarized from Abdullah Saydam's study. For details see (Saydam, 1993, p. 239-255); For the number of households of the resettled tribes see (Erdönmez, 1995, p. 89-93). together easily and engaging in banditry. The Pasha also considered distributing free land to tribes in order to encourage them to voluntarily settle in fertile areas such as Uzunyayla. During Vecihi Pasha's work, deterrent methods such as creating militia forces from troubled but loyal tribes such as Pehlivanli tribe were also used. The use of other encouraging methods, such as not resorting to force unless the resistance was encountered, being compassionate and fair to the tribes, settling them in the regions where they could live, providing assurance of life and property to the tribes where the settlements were carried out, and not receiving the first year tax from those who engage in agriculture also facilitated the tribal settlements ${ }^{6}$.

Another area where settlement practices were carried out was the southeast Mediterranean region of Anatolia. It was mentioned above that the main reasons for the settlement in this region, which were carried out under the administration of Cevdet Pasha and Dervis Pasha, were to obtain troops from the region and to end the semiautonomous administration of Kozanogulları. For this purpose, the Furka-i İslahiye consisting of selected soldiers of Turkish, Albanian, Georgian, Circassian and Kurdish origin was formed in 1865 by the Pashas whose names were mentioned. The staff committee of this unit was also composed of selected officers who were successful in various battles. Firka-i Íslahiye was initially established with the aim of bringing the regions from Iskenderun to Maras and Elbistan, from Kilis to Niğde and Kayseri, from Adana to the border of Sivas province, and the regions of Akçadağ and Dersim in eastern Anatolia under state authority (Ahmed Cevdet Paşa, 1980,p. 115) ${ }^{7}$. Of these, only in the first part, the area between İskenderun and Maraş, the rehabilitation and settlement was achieved (Ahmed Cevdet Paşa, 1980,p.178).

Firka-i İslahiye which came ashore at Iskenderun on 28 May 1865 carried out the rehabilitation and settlement practices together with a number of administrative arrangements. With this, it was probably intended to lay the groundwork for the implementation of the new Vilayet law, which came into force in November 1864 and was first implemented in the province of Tuna by Midhat Pasha (Ahmed Cevdet Paşa, 1980, p.177).

The Firka started its operation from the South, Gavur and Kurdish mountains, by settling the Reyhanli tribe living in the Amik plain and controlling and securing the Aleppo road. Afterwards, the tribes in the Kurdish Mountain Between Iskenderun and Marass were settled in the new districts named Izziye and Hassa and the Delikanlu and Ceelikanlu tribes in the Dumdum plain were settled in Islahiye district, which was formed by the unification of the surrounding sub-districts. This district, which was formed, was merged with İzziye, Hassa and Bulanık districts to form the İslahiye District Governorate and was affiliated to the Maras Governorate. Osmaniye, formerly a village, was transformed into a district center with the transfer of a large number of households from

7 For the detailed information about Fırka-i Islâhiye see (Çelik 2008). 
the Çukurova tribes, and was affiliated to the Sanjak of Payas (Halaçoğlu, 1973, p. 8-12).

After successful rehabilitation and settlement practices in the Gavur and Kurdish Mountains, The Firka moved north and continued its activities in the Cukurova and Kozan Mountains. The most important settlements in this region were carried out in Kars-1 Zülkadriye (Kadirli) and Sis (Kozan) towns. First, the ruined town of Kars-1 Zülkadriye, the center of the former Dulkadiroğulları Principality, was rebuilt, and a tribal community of approximately 600 households in the Cukurova mountains was transferred and settled there. In the meantime, this place was turned into a district center called Zülkadiriye. Likewise, Sis town was made the center of Kozan Sanjak, to which Kadirli and Belenköy districts are affiliated, after the settlement of many tribes (Halaçoğlu, 1973, p.13-19).

The effective methods used by Cevdet and Derviş Pashas during these settlement practices enabled the tribal settlement to be significantly successful. Although the operation in the region was a military type of operation, it was tried not to resort to military force as much as possible during the settlement practices. Before commencing the rehabilitation and settlement activities, a general amnesty was declared to those who had previously been bandits in the tribes in a wide region up to the borders of İskenderun, Maraş, Elbistan, Kilis, Niğde, Adana, Kayseri, Sivas, and thus it was ensured that some of them became subject to the state. In addition, by establishing a dialogue with the notable people of tribes and convincing them, some tribes were ensured to side with the state (Ahmed Cevdet Paşa, 1980, p. 131).

This method was applied especially in Kozan region and some of the tribes connected to Kozanogullar1 accepted the authority of Firka-i Islahiye and the power of Kozanogulları was significantly weakened. It should be noted that the compassionate and fair attitudes of the Firka administrators to the tribes and the inhabitants of the region also facilitated their settlement. For example, when some troops belonging to the army in the vicinity of Kerkütlü damaged the villagers' crops, the punishment of an officer responsible for this damage, and although hay, oil, onions and similar supplies had not been bought and sold with money in the region until that day, the purchase of them by the military administrators by paying for them increased their confidence in the state as well as reduced the influence of the local aghas and feudal lords (Ahmed Cevdet Paşa, 1980, p. 139-140, 144-146).

Another method used during the settlement and rehabilitation work was the appointment of the heads of some tribes in the districts and villages to the most remote places possible with various ranks and salaries. For example, the appointment of Ahmet Agha, one of the Chiefs of Kozanogulları, who is the largest and most powerful tribe in the region and who resisted the Firka-i Íslahiye for the longest time, to the governorship of Kütahya with the rank of Pasha, is the most important achievement of the administrators of the Firka in this regard (Ahmed Cevdet Paşa, 1980, p.163). In this way, one of the most important obstacles to the establishment of a centralized administration system was eliminated.
The activities of the Frrka-i Islahiye in the region pleased some tribes who were subjected to the pressure of the local dynasties such as the Kozanoğulları, but did not please the Avşars. The reason for this is that, during the rehabilitation work in Cukurova, Avşars, one of the largest tribes of Çukurova, was asked to be placed in the town of Aziziye, which is on the border with Sivas province. However, upon the reluctance of the Avşars, it was decided to abandon this plan and settle them in Uzunyayla, which has highlands. However, since Circassian immigrants were placed in Uzunyayla at this time, the Avşars were placed in regions close to here (Ahmed Cevdet Paşa, 1980, p. 147).

\section{CONCLUSION}

The settlements of semi-nomadic tribes during the Tanzimat period of Ottoman Empire should be considered as the application of the Tanzimat principles to the nomadic people of the Empire. The Tanzimat rulers deemed it necessary for the nomadic tribes to be settled in order for the general reform program, outlined by the Tanzimat Edict, to be fully implemented and for the country to achieve a modern appearance.

Ensuring the life and property security for the resident people threatened by the nomads, therefore protecting agriculture and trade, meeting the heavy need for soldiers in the army, closing the tax deficit by collecting the uncollectible taxes from this segment of the society and establishing a central management were only possible through settlement of the tribes.

For this purpose, extensive settlement practices were carried out in Central Anatolia and Southeastern Mediterranean regions between 1839-1865. Although the military force was used from time to time during the resettlement activities, in order to ensure the success of these settlements and to be permanent, encouraging methods were rather applied to ensurethe voluntary settling of the nomads.

Undoubtedly, it is only possible to determine whether the tribal settlement pratices carried out in these regions during the Tanzimat period have been successful or not only through demographic and agricultural history surveys to be conducted for the periods after the tribal settlements. However, the fact that there was a $10 \%$ increase in agricultural income between 1860-1876 due to the increase in agricultural production and the fact that agricultural taxes constituted a large part of the tax revenues in the Tanzimat period tax system suggest that the nomads who were settled got used to the sedentary lifestyle and started agriculture (Şener, 1992, p.268-269; Mustafa Nuri Paşa, 1987, p. 307). 


\section{Bibliography}

Abadan, Y. (1940). Tanzimat Fermanı'nın Tahlili. In Tanzimat (Vol. I, pp. 31-58). Ankara: Milli Eğitim Bakanlığı.

Abdurrahman Şeref Efendi. (1985). Tarih Musahabeleri. Ankara.

Abdurrahman Vefik. (1328). Tekâlif Kavâîdi. Dersaâdet.

Abdurrahman Vefik. (1330). Tekâlif Kavâidi. Darsaâdet.

Ahmed Cevdet Paşa. (1980). Ma'rûzât,. (Y. Halaçoğlu, Trans.) İstanbul.

Ahmed Lütfi Efendi. (1989). Vak'anüvis Ahmed Lütfi Efendi Tarihi (Vol. X). (C. Baysun, Trans.) Ankara.

Ahmed Refik. (1930.). Anadolu'da Türk Aşiretleri. İstanbul.

Akdağ, M. (1963). Celâli İsyanları 1550-1603. Ankara.

Akdağ, M. (1975). Osmanlı İmparatorluğu'nda Ayanlık Düzeni Devri 1730-1839. D.T.C.F. Tarih Araştırmaları Dergisi, XIV(23), 51-61.

Aktepe, M. (1953). XIV ve XVI. Asırda Rumeli'nin Türkler Tarafından İskânına Dair. Tarih Mecmuası, X, 304307.

Barkan, Ö. L. (1942). Osmanlı İmparatorluğunda Bir İskan ve Kolonizasyon Metodu Olarak Vakiflar ve Temlikler I: İstila Devirlerinin Kolonizatör Türk Dervişleri ve Zaviyeler. Vakıflar Dergisi(2), 279-386.

Barkan, Ö. L. (1951). Osmanlı İmparatorluğu'nda Bir İskân ve Kolonizasyon Metodu Olarak Sürgünler. Íktisat Fakültesi Mecmuası, XI, 525-569.

Barkan, Ö. L. (1953). Osmanlı İmparatorluğu'nda Bir İskân ve Kolonizasyon Metodu Olarak Sürgünler. İktisat Fakültesi Mecmuası, XIII, 56-78.

Bates, D. G. (1974). Shepherd Becomes Farmer A Study of Sedentarization and Social Change in Southeastern Turkeyll in Turkey. In Turkey: Geographic and Social Perspectives (pp. 92-136). Leiden.

Berkes, N. (1964.). Development of Secularism in Tukey. Montreal.

Berkes, N. (1973.). Türkiye'de Çağdaşlaşma. İstanbul.

Cevdet Paşa. (1986). Tezâkir (Vols. 21-39). Ankara.

Çelik, A. B. (2008). Ftrka-i Islahiye (Master's Thesis). Kahramanmaraş: Kahramanmaraş Sütçü İmam Üniversitesi Sosyal Bilimler Enstitüsü.

Çelikdemir, M. (2001). Osmanlı Döneminde Aşiretleri Rakka'ya İskanı (1690-1840) (Doctoral Dissertation). Elazığ: Firat University.

Davison, R. (1963). Reform in The Ottoman Empire. Princeton.
Dede, S. (2011). From Nomadism to Sedentary Life in Central Anatolia: The Case of Rişvan Tribe (18301932). (Master's Thesis). Ankara: İhsan Doğramac1 Bilkent University, Graduate School of Economics and Social Sciences.

Demir, A. (2017). Osmanlı Devleti'nde Yörükler ile Yerleşiklerin Kavgası: Kayıp Köyler Meselesi. Gazi Akademik Bakış, 11(21), 15-31.

Deringil, S. (2003). "They Live in a State of Nomadism and Savagery": The Late Ottoman Empire and the PostColonial Debate. Comparative Studies in Society and History, 45(2), 311-342.

Dumont, P. (1979-1980). 1865 Tarihinde Güney-Doğu Anadolu'nun Islahı. I.Ü.E.F. Tarih Enstitüsü Dergisi(10-11), 369-392.

Dumont, P. (1981). 1865 Tarihinde Güneydoğu Anadolu'nun Islah1. Tarih Enstitüsü Dergisi(10-11), 369-394.

Eberhard, W. (1953). Nomads and Farmers in Southeastern Turkey. Problems of Settlement. Oriens, 6(1), 32-49.

Erdönmez, C. (1995). Osmanlı İmparatorluğu'nun İskan Siyaseti ve Konar-Göçer Aşiretlerin Yerleştirilmesi (1840-1876). Master's Thesis. Samsun: Ondokuz Mayıs Üniversitesi Sosyal Bilimler Enstitüsü Tarih Bölümü Yakınçağ Tarihi Anabilim Dalı.

Faroqhi, S. (1976). Anadolu İskanı ve Terk edilmiş Köyler Sorunu. Türiye'de Toplumbilim Araştırmalarında Yaklaşımlar ve Yöntemler Semineri (17-19 Aralık 1976), (pp. 289-302). Ankara.

Gould, A. G. (1973). Pashas and Brigands: Ottoman Provincial Reform and its Impact on the Nomadic Tribes of Southern Anatolia, 1840-1885. Los Angeles: Ph.D., University of California.

Gökbilgin, T. (1957.). Rumeli'de Yürükler, Tatarlar ve Evlâd-ı Fâtihan. İstanbul.

Gündüz, T. (2007). Anadolu'da Türkmen Aşiretleri. İstanbul.

Halaçoğlu, Y. (1973). Fırka-i İslahiye ve Yapmış Olduğu İskân. İ.Ü. Edebiyat Fakültesi Tarih Dergisi,(27), 120.

Halaçoğlu, Y. (1991.). XVIII. Yüzyılda Osmanl İmparatorluğu'nun İskân Siyaseti ve Aşiretlerin Yerleştirilmesi,. Ankara.

İnalcık, H. (1940). Tanzimat Nedir? Yıllık Araştırmalar Dergisi, I, 237- 263.

Inalcik, H. (1954). Ottoman Methods of Conquest. Studia Islamica(2), 103-129.

İnalc1k, H. (1964). Sened-i İttifak ve Gülhâne Hatt-1 Hümâyûnu. Belleten, XXVIII(112), 602-622. 
İnalc1k, H. (1977). Centralization ve Decentralization in Ottoman Administration. In Studies in Eighteenth Century Ottoman History (pp. 27-52). London.

İzbırak, R. (1975). Coğrafya Terimleri Sözlüğü. Ankara.

Karal, E. Z. (1988). Osmanlı Tarihi (Vol. V). Ankara.

Kasaba, R. (2009). A Moveable Empire: Ottoman Nomads, Migrants, and Refugees. Seattle.

Kaynar, R. (1985). Mustafa Reşit Paşa ve Tanzimat. Ankara.

Kozanoğlu, A. M. (1983). Kozanoğulları. İstanbul.

Köksal, Y. (2006). Coercion and Mediation: Centralization and Sedentarization of Tribes in the OttomanEmpire. Middle Eastern Studies, 42(3), 469491.

Köse, M. Z. (2016). Kozanoğulları. Retrieved 25.11.2019, from TDV İslâm Ansiklopedisi: https://islamansiklopedisi.org.tr/kozanogullari

Kuran, E. (1994). Türkiye'nin Batılılaşması ve Milli Meseleler. Ankara.

Lewis, B. (1969). Emergence of Modern Turkey. London.

Lindner, R. P. (1983). Nomads and Ottomans in Mediaeval Anatolia. Bloomingto.

Mert, Ö. (1991). Âyân. In T.D.V. İslâm Ansiklopedisi (Vol. IV, pp. 195-198.). İstanbul.

Mustafa Nuri Paşa. (1987). Netâyic ül-Vukuât (Vols. IIIIV). (N. Çağatay, Trans.) Ankara.

Ocak, A. Y. (1996). Babaıler isyant: Aleviliğin Tarihsel Altyapist. İstanbul.

Orhonlu, C. (1978). Osmanlı İmparatorluğunda Aşiretlerin İskânı. İstanbul.

Özkaya, Y. (1977). Osmanlı İmparatorluğunda Âyânlık. Ankara.

Öztelli, C. (1976). Uyan Padişahım. İstanbul.

Sansar, M. F. (2006). Firka-i Islahiye ve Osmaniye (Cebel$i$ Bereket). Osmaniye.

Sansar, M. F. (n.d.). Tanzimat Döneminde Aşiretlerin İskânt. Retrieved 10 24, 2019, from TarihTarih.Com: https: / / www.tarihtarih.com/?Syf=26\&Syz=351262 \&/Tanzimat-D\%C3\%B6nemindeA\%C5\%9Firetlerin-\%C4\%B0sk\%C3\%A2n\%C4\%B1/-M.-Fatih-Sansar-

Saydam, A. (1993). Orta Anadolu'daki Aşiretlerin İskânı ( 1839-1853). In Prof. Dr. Bayram Kodaman'a Armağan (pp. 227-256.). Samsun.

Saydam, A. (1999). Reform ve Engeller: Tanzîmat Dönemi'nde Assiretlerin Yol Açtıkları Asayiş Problemleri. In Osmanlı (Vol. 4, pp. 180-189). Ankara: Yeni Türkiye Yayınları.
Seyitdanlığlu, M. (1996). Sadık Rıfat Paşa ve Avrupa'nın Ahvâline Dîr Risalesi. Liberal Düşünce(3), 115-124.

Shaw, S. (1975). The Nineteenth Century Ottoman Tax Reforms and Revenue System. International Journal of Middle East Studies, VI, 421-459.

Shaw, S., \& Shaw, E. K. (2002). History of The Ottoman Empire and Modern Turkey (Vol. II). Cambridge.

Stanford, S. (1997). History of The Ottoman Empire and Modern Turkey (Vol. I). Cambridge.

Şahin, İ. (2006). Osmanlı Döneminde Konar-Göçerler. İstanbul.

Şener, A. (1992). Tanzimat dönemi Osmanlı Vergi Reformları. In 150. Yılında Tanzimat (pp. 259-275). Ankara.

Şentürk, M. H. (1993, Nisan). Osmanlı Devleti'nin Kuruluş Devrinde Rumeli'de Uyguladığı İskân Siyâseti ve Nticeleri. Belleten, LVII(218), 89-112.

Şimşek, V. (2005). Ottoman Military Recruitment and The Recruit 1826-1853 (Master's Thesis). Ankara: The Institute of Economics and Social Sciences of Bilkent University.

Takvim-i Vekâyi. (1255, N 15). (187)

Tanoğlu, A. (1954). İskân coğrafyas1, Esas Fikirler, Problemler ve Metod. Türkiyat Mecmuası, XI, 1-34.

Tekeli, İ. (2008). Osmanlı İmparatorluğu'ndan Günümüze Nüfusun Zorunlu Yer Değiștirmesi ve İskân Sorunu. In Göç ve Ötesi. İstanbul: Tarih Vakfı Yurt Yayınları.

Uzunçarş1lı, İ. H. (1983). Osmanlı Tarihi (Vol. III/1). Ankara.

Winter, S. (2017). The Reşwan Kurds and Ottoman Tribal Settlement. Oriente Moderno(97), 256-269. 